\begin{abstract}
一論文—
（日本化学会誌，1995，（1），p. 25～29）

(C) 1995 The Chemical Society of Japan

\section{水熱法によるヒドロキシアパタイトホイスカーの合成}

\author{
(1994年 6 月 14 日受理)
}

浅岡伸之*. 須田洋幸**.吉村昌弘

ヒドロキシアパタイト(HAp) の化学的性質の一つである結晶学的異方性を積極的に活用するため, $c$ 軸方向に伸長したホイスカー状 HAp 結晶を合成する方法について検討した. 湿式法で調製した $\mathrm{HAp}$ スラリーにクエン酸を加えて溶解した液をオートクレーブに入れて, $180 \sim 220^{\circ} \mathrm{C}, 0 \sim 10$ 時間の 条件で水熱処理した. 固形分濃度 $1.7 \mathrm{wt} \%$ の HAp スラリーから調製した試料の場合, $200{ }^{\circ} \mathrm{C}, 3$ 時間以 上の水熱処理により, 長さ10 30 $\mu \mathrm{m}$, 直径約 $0.5 \mu \mathrm{m}$ の HAp ホイスカーが単相で得られた. しかし, 3 時間未満の水熱処理では HAp とモネタイトの混合相が析出して, 時間が短いほどモネタイトの割合 が高かった．これに対して, 固形分濃度 $4.4 \mathrm{wt} \%$ のスラリーを用いた場合には, クエン酸添加量を変化 させても, 得られた析出物はいずれも板状のモネタイトが主で, HAp は少量の長さ $5 \mu \mathrm{m}$ 以下の微細 な結晶しか見られなかった。
\end{abstract}

\section{1 緒言}

ヒドロキシアパタイト $(\mathrm{HAp})$ は $\mathrm{Ca}_{10}\left(\mathrm{PO}_{4}\right)_{6}(\mathrm{OH})_{2}$ の化学式 で表されるカルシウムリン酸塩の一種で, 人体の硬組織を構成す る主要成分である. そのため, 生体親和性に極めて優れた生体活 性な材料であり，畨科や整形外科の領域で既に人工歯や骨補填材 などとして実用化されている12)。さらにHApはタンパク質な どの高分子の吸着能力にむ優れていることから，クロマトグラフ ィー用カラム充填材あるいは細胞培着用担体など生化学の分野で も利用されている314).HAp は結晶学的には六方晶系に属してお り，六角柱状の自形を呈することが多い。結晶上には六角柱の側 面に相当する $\mathrm{a}$ 面 $(\mathrm{hk} 0)$ と底面に相当する $\mathrm{c}$ 面 $(00 l)$ の 2 種類 の結晶面が存在する. a 面の表面が 2 個の Ca 原子により構成さ れる(Cサイト) のに対して，c 面の表面はリン原子に付属する 6 個の酸素原子によって構成されている(Pサイト). そのため, これらの結晶面は異なった化学的性質を示し5)6), アルブミンな どの酸性タンパク質は a 面上にシトクロム c などの塩基性タン パク質は c 面上にそれぞれ選択的に吸着されやすいと言われて いる7).

ところで, 従来の HAp を用いたカラム材では塩基性タンパク 質に比べて酸性タンパク質の分離性能が劣るという問題点があっ た.そこで著者らは $c$ 軸方向に伸長した HAp 結晶を合成して, $\mathrm{a}$ 面の面積を $\mathrm{c}$ 面のそれに対して相対的に大きくすれば，酸性夕 ンパク質の分離・吸着特性も優れた HAp カラム材を得ることが

東京工業大学工業材料研究所, 227 横浜市緑区長津田町 4259

* 三菱マテリアル株式会社電子技術研究所, 368 埼玉県秩 父郡横瀬町大字横瀬 2270

** 工業技術院物質工学工業技術研究所, 305 つくば市東 $1-1$
できると考えた. HAp の針状〜ホイスカー状結晶を合成する試 みは、これまでMortier ら $5^{8)}$ ，木下ら ${ }^{9) 10) ， お よ ひ ゙ C h r i s t i a n s e n ~}$

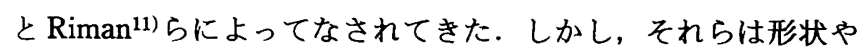
組成が必ずしも均一でなかったり, 結晶性が低い, といった問題 を含んでいた．これらを解決するため, 著者らの研究グループで は水熱処理によるHAp 粒子の形態制御法に取り組んでき た12) 15). そして，HAp スラリーに錯化剂を添加して水熱処理 することによって, アスペクト比が10以上の針状 HAp 結晶を得 ることに成功した ${ }^{16) 17)}$. 本研究ではさらにアスペクト比を增大 して特性の改善を図るとともに，さらに様々な用途への応用が期 待される HAp ホイスカーを合成するため，原料調製及び氷熱処 理の条件について調べた.

\section{2 実験}

実験フローチャートを図 1 にまとめた．出発物質である HAp スラリーは 5 モルの水酸化カルシウムと 3 モルのリン酸を蒸留 水中で混合，反応させる湿式法により合成した。すすなわち，この 原夜のカルシウム/リンモル比 $(\mathrm{Ca} / \mathrm{P})$ は1.67である，得られた スラリー中の HAp 濃度は $4.4 \mathrm{wt} \%$ でり，この一部を蒸留水で さらに希釈して $1.7 \mathrm{wt} \%$ に調整した.これら 2 種類の㳻度のスラ リーに錯化㓮としてクエン酸を添加して，HAp 粒子を容解させ た. クエン酸の添加量はHAp 1 モルに対して10〜17モルの籁囲 で変化させた、試料容液は $1.0 \mathrm{dm}^{3}$ のテフロンビーカーに入れ て, 容量 $5.0 \mathrm{dm}^{3}$ のオートクレーブ中で $180 \sim 220{ }^{\circ} \mathrm{C} て ゙$ 水熱処理 した．昇温速度は $2.5^{\circ} \mathrm{C} / \mathrm{min}$ ，設定温度での保持時間は $0 \sim 10$ 時 間で，冷却は自然放冷とした．また乐熱処理中の溶液温度及び浱 度の均質化を図るため, 取り出すまで100 rpmでかきませ続け た. 析出物は沪過・純水洗净後, $80{ }^{\circ} \mathrm{C}$ で24 時間乾燥させた。

析出物の結晶相同定には粉末 X 線回折装置 $(\mathrm{XRD}:$ 理学電機

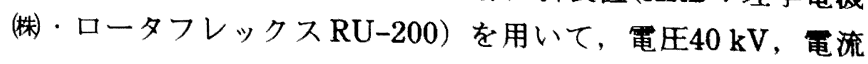




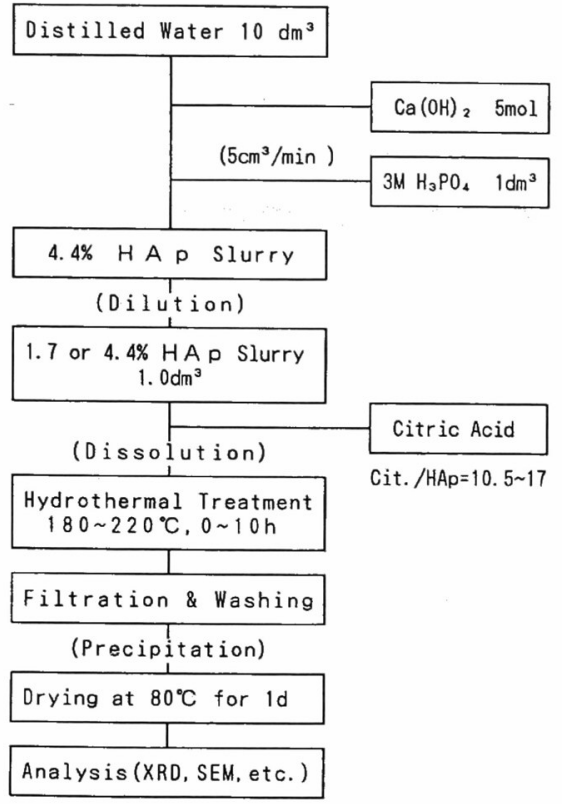

Fig. 1 Experimental procedure

$100 \mathrm{~mA}$ ，走査速度 $(2 \theta) 4 \mathrm{deg} / \mathrm{min}$ で測定した。結晶の形態は 走査型電子影微鏡 $(\mathrm{SEM}$ : 日本電子(侏) JSM-T200) を用いて, 加速電圧 $25 \mathrm{keV}$ で二次電子像を観察した。

\section{3 結果亡考察}

\section{(a) 水熱処理による試料の変化}

クエン酸の添加量が14.8モル比以上であれば，HAp スラリー は完全に溶解して，無色透明な液が得られた。水熱処理時, 200 ${ }^{\circ} \mathrm{C}$ 到達直後のオートクレーブ内圧は $2.0 \mathrm{MPa}$ であったのに対し て, 時間とともに圧力は徐々に上昇して, 3 時間経過以降 2.3 MPa でほほ一定になった．室温まで冷却すると，いずれの場合 にも沈激が見られた。溶液は薄黄色を呈し， $\mathrm{pH}$ も昇した (HAp スラリー濃度1.7 wt\%, Cit./HAp=14.8の場合3.1 $\rightarrow 3.4$ ). 沈海は淡褐色で，水や有機溶媒で洗浄しても脱色することはでき なかった. $\mathrm{X}$ 線回折の結果，析出物は溶液調製及び水熱処理条 件により $\mathrm{HAp}$ ホイスカー, モネタイト $\left(\mathrm{CaHPO}_{4}\right)$ のいずれか, または両者の混合相であった．得られた HAp ホイスカーは既 報17) と同様に $\mathrm{CO}_{2}$ の含有量が極めて少量であることを確認した.

HAp ホイスカーの XRD パターンを湿式合成 HAp のものと比 較すると, ホイスカーHAp の(002)面のピークは湿式 HAp のそ れより小さい。これに対して(300)面のピークはホイスカーの方 が異常に高い(図2). 各パターンにおける(300)面と(002)面の 回折強度比 $\left(I_{(300)} / I_{(002)}\right)$ も湿式 HAp の 1.72 に対してホイスカー は2.07と大きい.このことはホイスカーの伸長方向が $c$ 軸に一致 していて，(hk0）面の面積が相対的に大きい結晶が生成してい ることを示している.

\section{(b) スラリー濃度の影響}

濃度の異なる 2 種類の HAp スラリー(1.7 wt\% と $4.4 \mathrm{wt} \%)$ $1.0 \mathrm{dm}^{3}$ をそれそれ14.8モル比のクエン酸で浴解し, $200{ }^{\circ} \mathrm{C}$ で 5 時間水熱処理した. 両者の析出物のSEM 写真を図 3 に示した. $1.7 \mathrm{wt} \%$ のスラリーからは, 長さが $10 \sim 30 \mu \mathrm{m}$, 直径約 $0.5 \mu \mathrm{m}$,

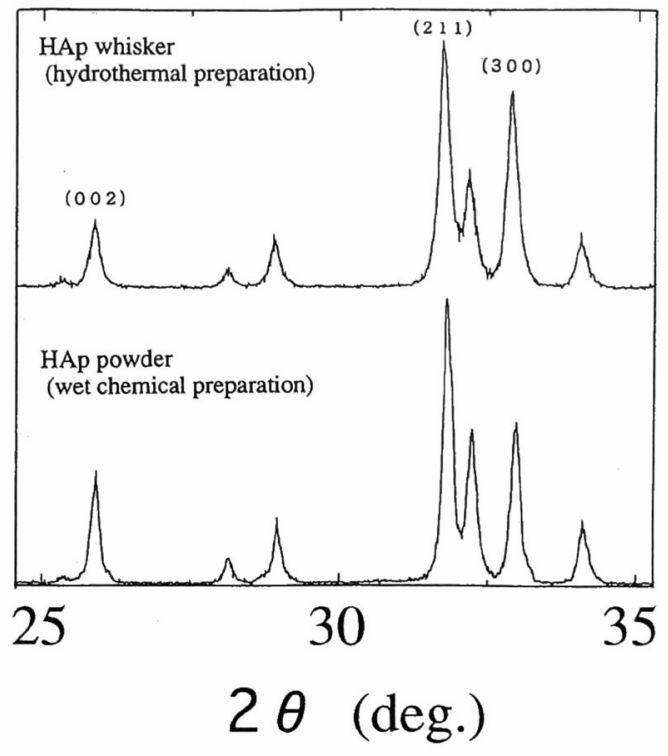

Fig. 2 XRD patterns of the HAp obtained from the different processes

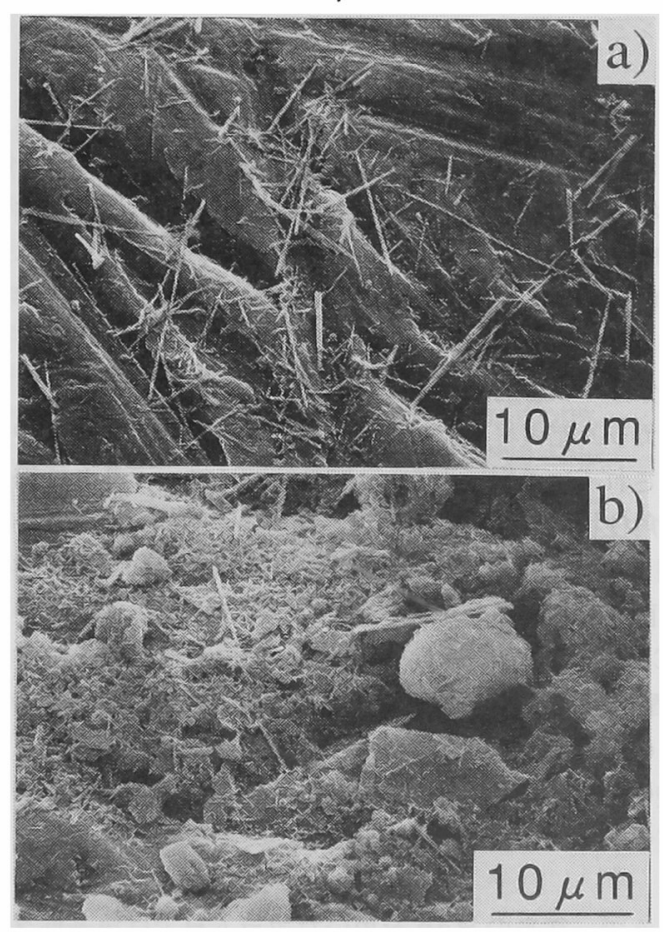

Fig. 3 SEM images of the hydrothermal products from the different HAp slurries of a) $1.7 \mathrm{wt} \%$ and b) $4.4 \mathrm{wt} \%$

アスペクト比20〜50程度の HAp ホイスカーが単相で得られたの に対して，4.4 wt\%のスラリーから得られたものは板状および塊 状のモネタイト結晶と少量の長さ $5 \mu \mathrm{m}$ 以下の微細な HAp 針状 結晶の混合物であった. スラリー濃度による析出相の違いは, 濃 度が高いと反応が十分に進行しないことと, HApの溶解度がも ともと低いため，高濃度では結晶核が大量に析出することが原因 ではないかと考えられる。 


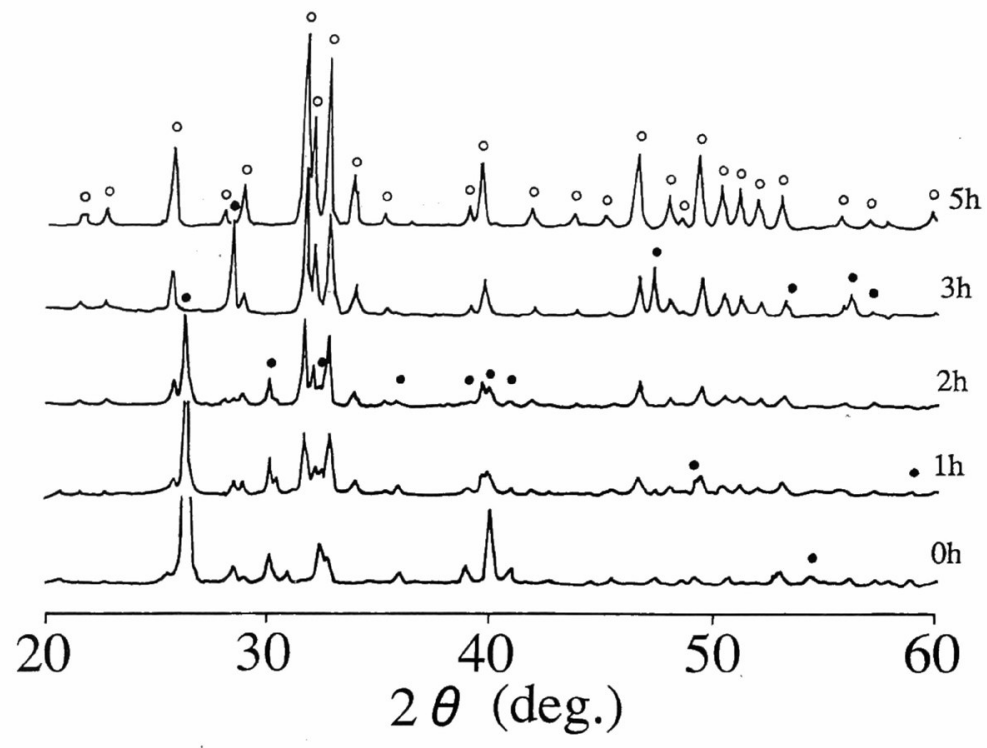

Fig. 4 XRD patterns of the hydrothermal products with different holding time at $200{ }^{\circ} \mathrm{C}$. Open and closed circles indicate the diffraction peaks of HAp and DCPA, respectively

\section{(c) クエン酸/HAp モル比の影罾}

濃度4.4 wt\%の HAp スラリーを用いて，クエン酸の添加モル 比を10.5〜17に変化させた. 14.8モル比未満では試料は完全には 溶解せず，白濁していたが，そのまま水熱処理した.クエン酸添 加量に伴い, 溶液の $\mathrm{pH}$ は3.18 2.80に変化したが, いずれの析 出物もほとんどがモネタイトで, HAp は14.8モル比以下の時に, わずかに含まれるだけであった。

\section{（d）水熱処理条件の影響}

水熱処理条件の検討には濃度 $1.7 \mathrm{wt} \%$ のスラリーを 14.8 モル比

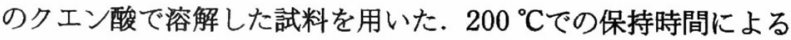
析出物の XRD パターンの変化を図 4 に示した，ここで保持時間 0 とは $200{ }^{\circ} \mathrm{C}$ 到達後, 即座に冷却を開始したことを意味する。 た各データは別個の試料を水熱処理した結果で, 一試料を連続的 にサンプリングしたものではない。これによれば保持時間 0 の 場合には，モネタイトが単相で析出したのに対して，1時間以上 保持すれば HAp も析出し, そのピーク強度は時間とともに増大 した．そして 3 時間以上の保持によって，ほほ HAp 単相になっ た.これと対応して SEM 像(図 5) も，保持時間 0 では細長い 短冊状のモネタイト結晶ばかりであるが, 長く保持するにつれて 針状〜ホイスカーの HAp 結晶の比率が高まった．また 5 時間ま での範囲で，HAp 結晶の大きさも時間とともに大きくなる傾向 が認められた。

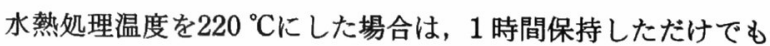

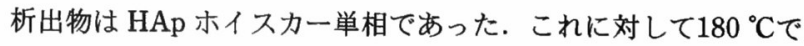
は10 時間保持しても析出物はモネタイトで, HAp は検出されな かった.

一方, 保持時間 0 でモネタイトが析出した試料を沈激・溶液 ごとそのまま再度 $200{ }^{\circ} \mathrm{C} て ゙ 5$ 時間水熱処理した結果, 析出物から 板状のモネタイト結晶が消减し, HAp ホイスカー単相になった(図 6,7).これらの結果から，水熱処理の初期にモネタイトが析出 して, その後 HApに変化した，という可能性も考えられる. し かしモネタイトがいつ析出しているかが明らかでないため, 断言

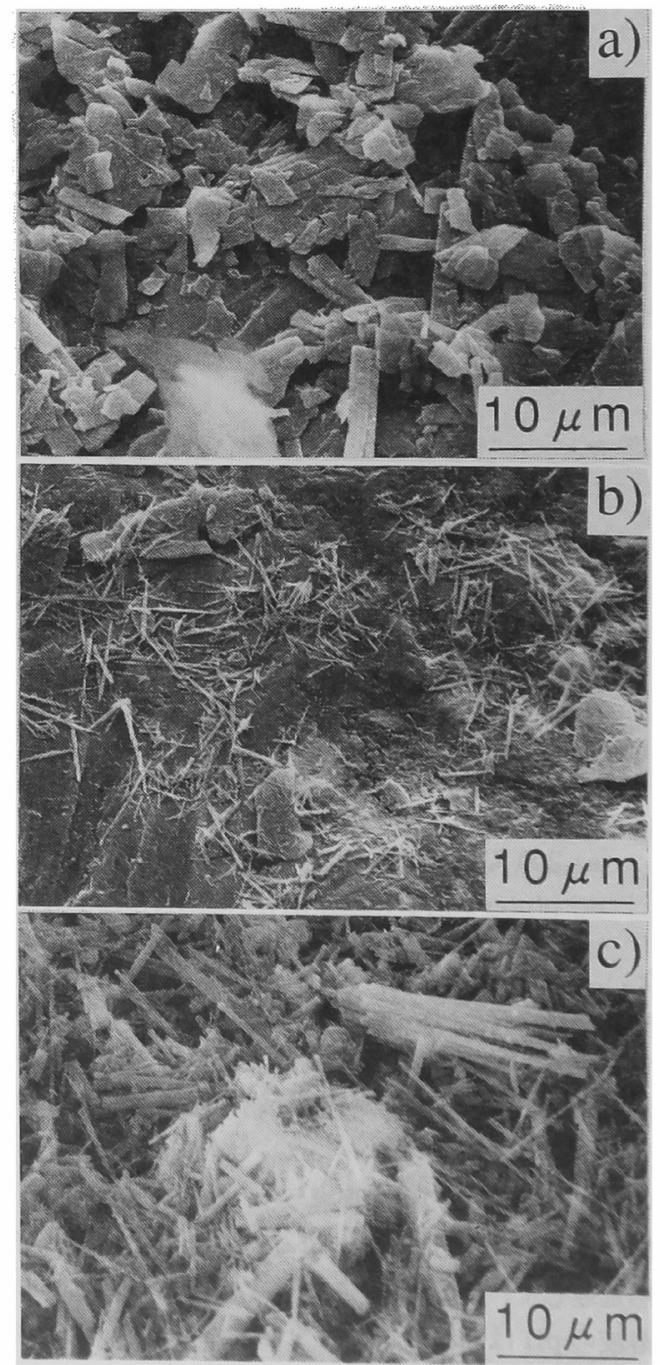

Fig. 5 SEM images of the hydrothermal products held at $200{ }^{\circ} \mathrm{C}$ for a) $0 \mathrm{~h}$, b) $2 \mathrm{~h}$ and c) $5 \mathrm{~h}$ 


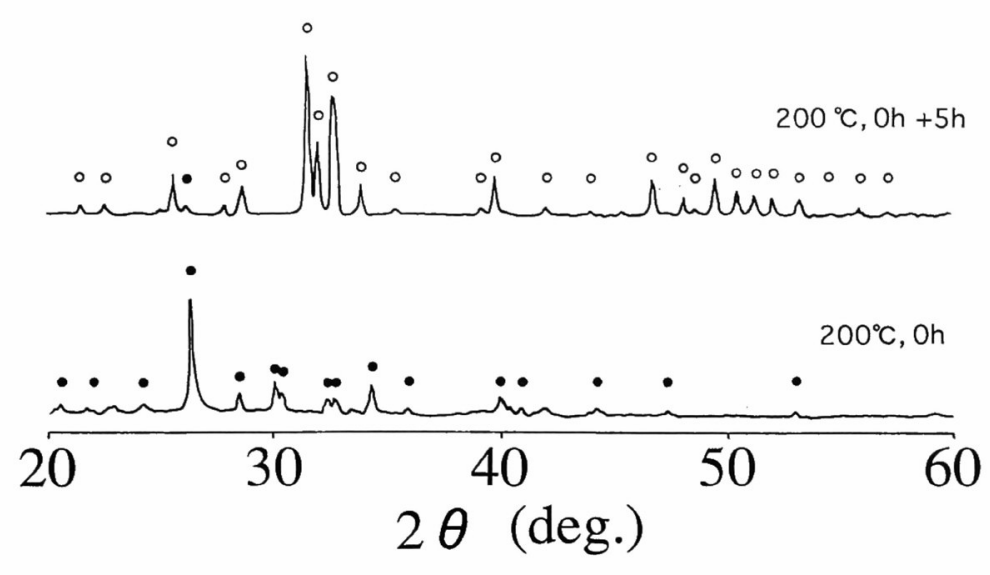

Fig. 6 XRD patterns of the products with single (lower) and double (upper) hydrothermal cycles. Open and closed circles indicate the diffraction peaks of HAp and DCPA, respectively

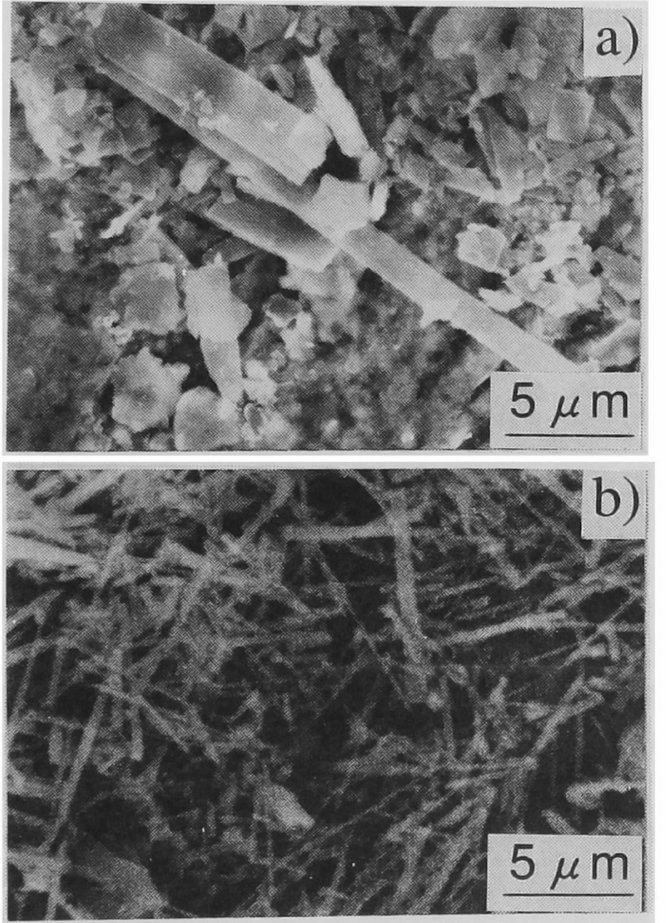

Fig. 7 SEM images of the same specimens as Fig. 6 . a) $200^{\circ} \mathrm{C}, 0 \mathrm{~h}$ and b) $200{ }^{\circ} \mathrm{C}, 0 \mathrm{~h}+200^{\circ} \mathrm{C}, 5 \mathrm{~h}$

はできない. たた，仮にモネタイトが析出したとしても，再度の 水熱処理によって HAp ホイスカーに変化し得ること, HAp, モ ネタイトともに溶解度が負の温度特性を有すること, などを考え 合わせると, モネタイトが水熱処理の初期に析出している可能性 は高い.

(e) HAp ホイスカーの生成機構

本実験では HAp スラリーをクエン酸で溶解した水容液を 200 ${ }^{\circ} \mathrm{C}$ で水熱処理して, HAp ホイスカーを合成している. 水熱処理 前の水溶液の $\mathrm{pH}$ は 3 程度で酸性であるが, スラリー中の HAp 微粒子の溶解については, 単に $\mathrm{pH}$ の問題ではなく, クエン酸の 添加によるカルシウム・クエン酸錯体の生成（ク溶性）が関与し
(1)

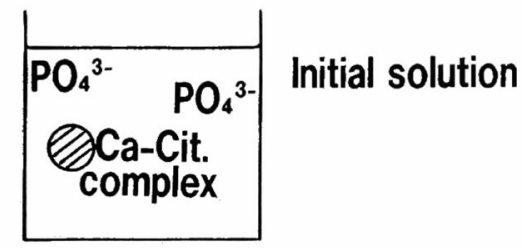

(2)

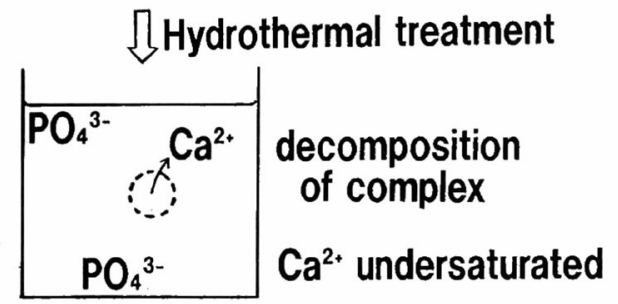

(3)

$\int$ Hydrothermal treatment

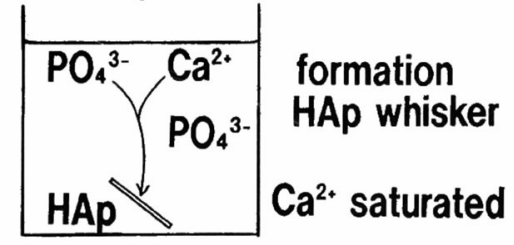

Fig. 8 Schematic figure of the HAp whisker formation under the hydrothermal condition
ているむのと考えられる. 水熱処理による HAp ホイスカーの生 成機構の模式図を図 8 に示した。このモデルでは，まず錯体の 母体であるクエン酸またはその誘導体が水熱分解して, $\mathrm{Ca}^{2+} 1$ オンを放出し，これと溶液中の $\mathrm{PO}_{4}{ }^{3-}$ イオンが溶解度積を超え て析出する, という生成機構を表している, この時, $\mathrm{pH}$ 3.0 ３.5という酸性領域で HAp ホイスカーが析出する理由につ いて, 今回の結果をもとに検討した. 水熱処理時間が長くなると 析出相はモネタイトから HAp へ変化する, 一度モネタイトが析 出しても, さらに水熱処理を続けると HAp になる, HAp 濃度 が高い試料溶液からは HAp が析出しにくい, などの析出状況を 考えると, 溶解度が関与している可能性が高い.すなわち, 時間 とともにカルシウムのクエン酸誘導体錯体の分解が進行し, 錯体 
から放出された $\mathrm{Ca}^{2+}$ 濃度が溶液中の $\mathrm{PO}_{4}{ }^{3-}$ イオン濃度に対して 上昇することにより，モネタイトよりも $\mathrm{Ca} / \mathrm{P}$ 比が高い $\mathrm{HAp}$ 相 が安定化するのではないかと考えられる，また皮熱条件下におけ る $\mathrm{HAp} /$ モネタイト相境界のシフトにより，予想される $\mathrm{pH}$ 值よ

りも低い $\mathrm{pH}$ 側で HAp 生成が起こることと考えられる.

なお， $c$ 軸方向に伸長してホイスカーに成長する理由について は a 面への反応物質の吸着によるマスキング効果が可能性に挙 げられるが，現在のところ明らかではない。

\section{4 結 論}

HAp スラリーをクエン酸で溶解して, 水熱処理することによ り, HAp ホイスカーが得られた.このホイスカーは長さ $10 〜 30$ $\mu \mathrm{m}$, 直径約 $0.5 \mu \mathrm{m}$, アスペクト比 $20 \sim 50$ で, 結晶方位の $c$ 軸 方向に伸長していた. 出発試料の HAp 濃度が高かったり水熱処 理時間が短いとHAp ホイスカーの代わりにモネタイトが生成し やすい傾向が見られた，水熱処理時間が長くなるほどHAp ホイ スカーの生成量は増加し, 粒子径も大きかった。

本研究実施中に貴重な助言を賜りました, 東京工業大学工業材 料研究所の垣花葚人助教授，八島正知博士，三菱マテリアル株式 会社の竹内啓泰氏，岡本健吾氏に心から感謝致します.
1）青木秀希, 加藤一男, セラミックス, 10, 469(1975).

2) 大西正俊, 山渏安晴, 仲井義信, 小木曽誠, 歯科シャ一 ナル, 17, 623(1983).

3）青木秀希, 加藤一男, 赤尾 勝, 組織培養, 6, 42(1980).

4) 中村孝司, セラミックス, 23, 1065(1988).

5) T. Kawasaki, J. Chromatogr., 151, 95(1978).

6) T. Kawasaki, J. Chromatogr., 157, 7(1978).

7）川崎 力, セラミックス, 20, 195(1985).

8) A. Mortier, L. Lemaitre, J. Solid State Chem., 26, 215(1989).

9）木下真喜雄, 岸岡 昭, 板谷清司, 林 英子, 石高と石 灰, 219, 23(1989).

10）木下真喜雄, 板谷清司, 中村清一郎, 岸岡 昭, 石高と 石灰, 227, 19(1990).

11) N. Christiansen, R. E. Riman, Proc. 5th Scandinavian Symp. Mater. Sci., 1989, 209.

12）井奥洪二, 吉村昌弘, 宗宮重行, 日化, 1988, 1565.

13) K. Ioku, M. Yoshimura, S. Somiya, "Bioceramics" Vol. 1, (Proc. 1st International Bioceramic Symp.) P. 62 (1989).

14）井奥洪二, 野間竜男, 石沢伸夫, 吉村昌弘, 日本セラミ ックス協会学術論文誌, 98, 1337(1990).

15）吉村昌弘, 須田洋幸, 岡本健吾, 井奥洪二, 日化, $1991,1402$.

16）吉村昌弘, 須田洋幸, 浅岡伸之, 井奥洪二, 岡本健吾, 日本セラミックス協会年会 (1991) 予稿集, pp. 131-136.

17) M. Yoshimura, H. Suda, K. Okamoto, K. Ioku, J. Mater. Sci., 29, 3399(1994).

\title{
Preparation of Hydroxyapatite Whiskers by Hydrothermal Method
}

\author{
Nobuyuki ASAOKA*, Hiroyuki SUDA** and Masahiro YoSHIMURA \\ Research Laboratory of Engineering Materials, Tokyo Institute of Technology; \\ 4259 Nagatsuta-cho, Midori-ku, Yokohama-shi 227 Japan \\ *Electronics Technology Research Center, Mitsubishi Materials Corporation; \\ 2270 Yokoze-machi, Chichibu-gun 368 Japan \\ **National Institute of Materials and Chemical Research; \\ 1-1 Higashi tsukuba-shi 305 Japan
}

Hydroxyapatite (HAp) whiskers, which are elongated along the crystallographic $c$-axis, were synthesised under hydrothermal method using citric acid. Starting HAp slurries with two different concentrations of 1.7 and $4.4 \mathrm{wt} \%$ were prepared by a precipitation method, and became clear solutions by adding suitable amounts of citric acid (Cit.) to dissolve HAp particles. The solutions of $1.0 \mathrm{dm}^{3}$ were hydrothermally treated in an autoclave at a temperature from 180 to $220^{\circ} \mathrm{C}$ for $0,1,2,3,5$ and $10 \mathrm{~h}$. The crystalline phases of the products detected by powder X-ray diffractometry depended on both the concentration of HAp and the temperature and the duration of hydrothermal treatments. No HAp whiskers could be obtained from the solutions containing $4.4 \mathrm{wt} \%$ of HAp at any Cit./HAp ratio. They could be obtained, however, only from those of $1.7 \mathrm{wt} \%$ above a limited Cit./HAp molar ratio such as 14.8 . In addition, hydrothermal treatment for more than $3 \mathrm{~h}$ at $200{ }^{\circ} \mathrm{C}$ was necessary to synthesise HAp whiskers. The whiskers were from 10 to $30 \mu \mathrm{m}$ in length and about $0.5 \mu \mathrm{m}$ in diameter. However the weight proportion of HAp in the products rapidly decreased with the increasing that of plate-like calcium hydrogenphosphate anhydrate (DCPA: monetite) below $200{ }^{\circ} \mathrm{C}$ within the first $3 \mathrm{~h}$. 